\title{
Determinants of PhD student satisfaction: the roles of supervisor, department, and peer qualities
}

Article

Accepted Version

Dericks, G., Thompson, E., Roberts, M. and Phua, F. (2019) Determinants of PhD student satisfaction: the roles of supervisor, department, and peer qualities. Assessment \& Evaluation in Higher Education, 44 (7). pp. 1053-1068. ISSN 1469-297X doi:

https://doi.org/10.1080/02602938.2019.1570484 Available at https://centaur.reading.ac.uk/81463/

It is advisable to refer to the publisher's version if you intend to cite from the work. See Guidance on citing.

To link to this article DOI: http://dx.doi.org/10.1080/02602938.2019.1570484

Publisher: Routledge

All outputs in CentAUR are protected by Intellectual Property Rights law, including copyright law. Copyright and IPR is retained by the creators or other copyright holders. Terms and conditions for use of this material are defined in the End User Agreement. 


\section{CentAUR}

Central Archive at the University of Reading

Reading's research outputs online 
Full Title: Determinants of PhD Student Satisfaction: The roles of supervisor, department, and peer qualities

\section{Author names and addresses:}

Gerard H. Dericks

Oxford Brookes University

Oxford, OX3 0BP

UNITED KINGDOM

ORCiD: 0000-0001-6604-600X

Edmund R. Thompson

School of Management

University of Bath

Bath, BA2 7AY

UNITED KINGDOM

Email: e.r.thompson@bath.ac.uk

ORCiD: 0000-0003-1215-0447

Margaret Roberts

Faculty of Business and Law

University of West England

Bristol, BS16 1QY

UNITED KINGDOM

Florence T. T. Phua

School of Construction Management and Engineering

University of Reading

Reading, RG6 6AH

UNITED KINGDOM

\section{Corresponding author:}

Gerard H. Dericks

Email: gdericks@brookes.ac.uk

Phone: +44 (0)1865485433

\section{Acknowledgements}

We thank Professors Jurgen Enders, Christian Bokhove and Daniel Muijs for helpful comments and suggestions. 


\begin{abstract}
Understanding the determinants of $\mathrm{PhD}$ student satisfaction is likely to become increasingly vital for universities as student satisfaction rankings already ubiquitous at undergraduate and master degree levels extend more broadly to the $\mathrm{PhD}$ level. Moreover, as $\mathrm{PhD}$ student populations and university competition become increasingly transnational, there is a growing need to understand cross-nationally common determinants of satisfaction. Building on prior research into $\mathrm{PhD}$ student satisfaction, and drawing upon relevant conceptual and metrical refinements in the measurement of satisfaction from cognate domains of psychology, we use cross-sectional data $(N=409)$ from $\mathrm{PhD}$ candidates across the sciences, social sciences, and humanities in 63 universities from 20 countries to examine how overall $\mathrm{PhD}$ student satisfaction is determined by, respectively and in combination, supervisor, department, and peer-group, in terms of both their academic qualities and supportiveness. Taken together, we find that supervisor supportiveness is the greatest predictor of $\mathrm{PhD}$ student satisfaction, but that supervisor academic qualities have no significant effect. However, both the academic qualities and supportiveness of departments significantly predict PhD student satisfaction, suggesting university departments and PhD supervisors would ideally work jointly, and perhaps more closely than many currently do, to achieve competitive levels of PhD student satisfaction.
\end{abstract}

Key words: PhD-doctoral student satisfaction; supervisor; department; peers; academic qualities; supportiveness.

\title{
Introduction
}

With modern economies demanding ever higher levels of education, and with students themselves increasingly paying for their studies, students, universities and governments are becoming ever more concerned with the quality of education at undergraduate, master and $\mathrm{PhD}$ 
levels. One consequence of this, on the assumption it is related to educational quality, has been an increasing interest in student satisfaction. National governments now assess student satisfaction at both undergraduate and master degree levels, and there is little reason to doubt that formal government-sponsored assessment of $\mathrm{PhD}$ student satisfaction will likewise be integrated into university ranking and funding systems.

Existing undergraduate and master degree student satisfaction data are not just used by governments and funders in their efforts to assess and drive up the quality of education through rankings and league tables (Barnes and Randall 2012). Satisfaction scores are also known determinants of students' university selection (Gibbons, Neumayer, and Perkins 2015), motivation (Donohue and Wong 1997), retention (Roberts and Styron 2010), completion rates (Neumann and Rodwell 2009), performance (Pike 1993), willingness to recommend their institution to others (Allen and Davis 1991), and intention to provide financial support as alumni (Sung and Yang 2009).

While $\mathrm{PhD}$ student satisfaction data may not yet ubiquitously be collected by governments, PhD student satisfaction, whether assessed or not, would seem arguably to contribute to higher $\mathrm{PhD}$ student wellbeing and, possibly, performance. $\mathrm{PhD}$ student satisfaction might also contribute to the decision by new PhDs to pursue academic careers, thereby enhancing their alma maters' research networks and the higher education profession more broadly. Several extant studies on $\mathrm{PhD}$ student satisfaction suggest the issue is already considered important by education scholars. Typical examples of studies shedding light on PhD student satisfaction include those focusing on aspects of the role of the supervisor (Ives and Rowley 2005; Zhao, Golde, and McCormick 2007; Erichsen, Bolliger, and Halupa 2014), those investigating the role of departments (Morton and Thornley 2001; Umbach and Porter 2002; Golde 2005), and those examining the role of student peer and social networks (Deem and Brehony 2000; Pilbeam, Lloyd-Jones, and Denyer 2013). 
However, extant studies often focus mainly on just one or other possible determinant of PhD student satisfaction, and to date no study has sought to examine the extent to which the roles of supervisors, departments and peers in combination determine PhD student satisfaction. We attempt to build on current literature by examining how PhD student satisfaction across an international and discipline-diverse sample is predicted by supervisors, departments and peergroups, both individually and in combination, providing insights into their relative importance and their unique contributions to student satisfaction. Moreover, we seek to add nuance to these insights by drawing on prior non-PhD student satisfaction research suggesting student satisfaction stems from two discrete aspects of learning: on one hand, educators' scholarly expertise, what might be labelled 'academic qualities', and on the other, non-academic aspects of the learning context and environment that might succinctly be labelled 'supportiveness' (Hendry 1983; Pascarella and Terenzini 2005; Kuh et al. 2006). We take these two identified contributors to student satisfaction and apply them separately in relation to supervisors, to departments, and to peers. Hence we also examine discretely the roles of, respectively, the academic qualities and the supportiveness of, individually and in combination, supervisors, departments and student peers.

\section{Supervisors, departments and peer-group as determinants of student satisfaction}

A wide range of determinants of student satisfaction have been considered in prior research such as discipline of study (Barnes and Randall 2012), university reputation (LeBlanc and Nguyen 1997), class size (Deanne, Teegan, and Mertova 2018), quality of facilities (Han et al. 2018), and student attributes (Wiers-Jenssen, Stensaker, and Grogaard 2002). However for PhD student satisfaction, supervisors, departments and student peer-groups appear to predominate as potential determinants. 
It has sometimes been said that supervisors can 'make or break' a PhD student (Lee 2008, 267). Much research has been focussed specifically on the role of supervisors in $\mathrm{PhD}$ students’ experience (Bastalich 2017), with previous research demonstrating a significant influence of supervisors on not just completion outcomes (Jacks et al. 1983; Golde 2005; Ives and Rowley 2005; Martinsuo and Turkulainen 2011) but also specifically on PhD student satisfaction (Zhao, Golde, and McCormick 2007; Bedggood and Donovan 2012; Erichsen, Bolliger, and Halupa 2014).

Academic departments have also been shown in prior research broadly to have an effect on student satisfaction (Volkwein and Carbone 1994; Berger and Braxton 1998; Umbach and Porter 2002), with various departmental characteristics found to influence student adjustment, progression, success, and satisfaction (Pascarella and Terenzini 1977, 1991, 2005; Hockey 1994; Borden 1995; Kuh 2003; Golde 2005; Baker and Pifer 2015).

Scholars have also investigated the role of fellow students in various aspects of the $\mathrm{PhD}$ student experience (Boud and Lee 2005; Pilbeam and Denyer 2009; Fenge 2012; Pilbeam, Lloyd-Jones, and Denyer 2013), including academic development and research progress (Baldwin, Bedell, and Johnson 1997; Shacham and Od-Cohen 2009; Walsh 2010; Martinsuo and Turkulainen 2011). However, as yet, only at the undergraduate and master levels has research explicitly investigated the relationship between peer-groups and satisfaction (Harnash-Glezer and Meyer 1991; Volkwein and Carbone 1994; Wiers-Jenssen, Stensaker, and Grogaard 2002; Arambewela and Hall 2013).

\section{Academic qualities and supportiveness}

Reviews of student learning (Pascarella and Terenzini 2005; Kuh et al. 2006) highlight the role of students' appraisals of both the academic qualities and the supportiveness of their learning environments as predictors of their satisfaction. 
Academic qualities. Student satisfaction has been found to be heavily dependent on perceptions of their instructor's expertise and scholarly ability (Hendry 1983; Donald, Saroyan, and Denison 1995; Ives and Rowley 2005; Bedggood and Donovan 2012). However, wider departmental academic qualities and research emphasis have also been found to influence student satisfaction (Astin 1993; Volkwein and Carbone 1994; Umbach and Porter 2002), as has the academic-mindedness and scholarly ambition of fellow students (Spady 1970; Fenge 2012; Pilbeam, Lloyd-Jones, and Denyer 2013).

Supportive learning environment. Several studies have recognised the importance of broader supportiveness of the learning environment to student satisfaction. In relation specifically to supervisors, research has shown that a personally supportive nature is a major determinant of satisfaction and progress (Kam 1997; Zhao, Golde, and McCormick 2007; Martinsuo and Turkulainan 2011; Platow 2012; Erichsen, Bolliger, and Halupa 2014). Other research has highlighted the important supportive role of the wider department and university to satisfaction. For example, Umbach and Porter (2002) demonstrate that greater contact with departmental staff is associated with higher student satisfaction, with better integration into faculty and departmental communities associated with lower PhD-study abandonment (Girves and Wemmerus 1988; Hockey 1994; Golde 2005). Supportiveness of immediate student peergroups has also been found to contribute to student satisfaction, with good peer relations, positive peer climates, and extended peer networks contributing to satisfaction (HarnashGlezer and Meyer 1991; Baldwin, Bedell, and Johnson 1997; Wiers-Jenssen, Stensaker, and Grogaard 2002).

\section{Propositions}

Existing research cited above gives adequate suggestion that, separately, supervisors, departments and peer-groups each have an effect on PhD student satisfaction. Existing research 
also suggests that, respectively, academic qualities and supportiveness both have an effect on PhD student satisfaction. Hence we might reasonably set out the following propositions:

P1a. Supervisors' academic qualities will predict PhD student satisfaction.

P1b. Supervisors’ supportiveness will predict PhD student satisfaction.

P2a. Department academic qualities will predict PhD student satisfaction.

P2b. Department supportiveness will predict $P h D$ student satisfaction.

P3a. Peer-groups’ academic qualities will predict PhD student satisfaction.

P3b. Peer-groups’ supportiveness will predict PhD student satisfaction.

However, the absence of $\mathrm{PhD}$ student satisfaction research simultaneously examining, on one hand, the roles of supervisors, departments and peer-groups and, on the other, the separate roles of the academic qualities and supportiveness, necessarily leads us to more speculative propositions when considering which might be the largest predictors of student satisfaction.

With respect to the relative importance of supervisors, departments and peer-groups, combining both their academic qualities and supportiveness together in each case, we speculate that supervisors will be the largest predictor of PhD student satisfaction. The supervisor's role in the PhD student's experience would ostensibly seem paramount, and previous research comparing the relative importance of multiple determinants of student satisfaction generally support this view (Harnash-Glezer and Meyer 1991; Astin 1993; Krehbiel, McClure, and Pratsini 1997; Remedios and Lieberman 2008; de Kleijn et al. 2012). Hence we propose:

P4a. Supervisors' academic qualities and supportiveness combined will be a larger predictor of PhD student satisfaction than the academic qualities and supportiveness combined of either departments or peer-group.

Turning to the relative importance of departments versus peer-group in predicting $\mathrm{PhD}$ satisfaction, extant literature offers inconclusive results. The work of several scholars suggests 
that departmental factors should be more important than peers to $\mathrm{PhD}$ satisfaction (Liegler 1997; Clemes, Gan, and Kao 2007; Gruber et al. 2010). However, the work of other scholars suggests the opposite (Harnash-Glezer and Meyer 1991; Astin 1993; Wiers-Jenssen, Stensaker, and Grogaard 2002). Contradictory findings here are possibly the result of non-comparable operationalisations of department and peer characteristics. Nevertheless, research by Volkwein and Carbone (1994) and Umbach and Porter (2002) indicates that departmental factors clearly have an instrumental effect on satisfaction, whereas in a meta-analysis of student satisfaction studies Gibson (2010) found the role of peers to be only secondary. Hence, in the context of $\mathrm{PhD}$ student satisfaction, it would seem reasonable to propose that:

P4b. Department academic qualities and supportiveness combined will be a larger predictor of $\mathrm{PhD}$ student satisfaction than the academic qualities and supportiveness combined of PhD peer-group.

Contrasting the general importance of academic qualities and supportiveness, Kuh et al. (2006) maintain that some aspects of educational supportiveness may better promote students' commitment and persistence in graduating. This assertion is further supported by Salmon (1992), Gardner (2007), Bedggood and Donovan (2012), and de Kleijn et al. (2012) whose work suggests that an agreeable supervisory relationship and personal support are more important for student satisfaction than supervisor academic ability and knowledge. Moreover with respect to the university experience as a whole, Elliot and Healy (2001) and Overall, Deane, and Peterson (2011) likewise determined that the perception by students that they were welcome and valued was the strongest determinant of their satisfaction, surpassing instructional effectiveness. These conclusions lead us to the following proposition:

P5. Supportiveness will be a larger predictor than academic qualities of $P h D$ student satisfaction. 


\section{Methods}

\section{Sample and procedure}

We sought a heterogeneous sample to obtain results reasonably robust to generalisation. Student satisfaction scholars have underlined potential restrictions to generalisability stemming from single discipline samples (Liegler 1997; Mai 2005; Appleton-Knapp and Krentler 2006). Accordingly, we obtained data from $\mathrm{PhD}$ students across sciences, social sciences, and humanities. Other student satisfaction researchers highlight potential limitations of using single-university samples (Harnash-Glezer and Meyer 1991; Husbands 1996; Umbach and Porter 2002; Egan et al. 2009; de Kleijn et al. 2012; Berbegal-Mirabent, Mas-Machuca, and Marimon 2016; Pedro and Franco 2016; Maxwell-Stuart et al. 2018), hence we sought data from PhD students in multiple universities, 63 in total. Still other researchers have noted possible problems of generalisability using single-country samples (Wiers-Jenssen, Stensaker, and Grogaard 2002; Neumann and Rodwell 2009; Arena, Arnaboldi, and Azzone 2010; Arambewela and Hall 2013; Ali et al. 2016). So we endeavoured to obtain an international sample, ultimately getting responses from 20 countries across North America, Europe, and the Asia-Pacific, with some 54\% from Anglophone countries.

We pilot-tested an online instrument using our own $\mathrm{PhD}$ students as the sample. A finalised instrument was then administered by asking professional academic colleagues across disciplines and around the world to forward an invitation email with embedded instrument link to their current PhD students. We stressed that we wanted to sample candidates doing researchbased PhDs and not those doing taught or professional doctorates with scant, if any, substantive original theorisation, research or analysis component. Ours is hence a convenience sample. Instruments were completed anonymously. A total sample of 409 fully completed responses was thus achieved, descriptive statistics for which are given in Table 1.

$=$ INSERT TABLE $1 .=$ 


\section{Measures}

\section{Dependent variable}

Though definitions and measures of student satisfaction have varied considerably, student satisfaction is explicitly or implicitly conceptualised as an overall positive attitudinal response to an educational experience (Athiyaman 1997; Elliott and Healy 2001; Helgesen and Nesset 2007). As such, student satisfaction is inherently a unitary affective construct capturing an overall feeling towards an overall educational experience. Hence, student satisfaction is most appropriately and directly measured with items tapping how students subjectively feel about their educational experience as a whole.

Some research overtly conceives and consonantly measures student satisfaction directly as an overall affective construct (e.g. Clemes, Gan, and Kao 2007). Other research conceptualises student satisfaction as an overall affective construct but seeks to measure it indirectly through cognitive appraisal of particular facets of an educational experience or environment. Such cognitive measurements assume that overall affective student satisfaction can be measured vicariously through summation of satisfaction or performance scores relating to varying numbers of varying facets of an educational experience or environment. For example, Elliott and Shin (2002) conceptualise student satisfaction as an overall 'affective student outcome' (198), but opt for a cognitive measurement approach comprising assessments of specific conditions such as having a 'safe and secure campus' and being 'able to get desired classes’ (202). Arambewela and Hall (2013) again would seem to conceptualise student satisfaction affectively as 'satisfaction with [the] overall educational experience', but choose to operationalise their measurement with a 'composite construct, which is a summated measure of satisfaction with key aspects of the internal and external university environments' (973). Similarly, Barnes and Randall (2012) conceive PhD student satisfaction affectively as 'levels of overall satisfaction’ (56) but decide to use a cognitive measurement approach 
comprising a summated scale including items like 'I am satisfied with the amount of time I spend with my advisor' and 'I am learning good research practices' (72).

Cognitive conceptualisations and measurements of student satisfaction can, of course, be useful in the specific research settings for which they are explicitly used. However, to assume that affective student satisfaction is measurable by a summation of cognitively assessed satisfaction with any given set of facets of an educational experience can be problematic. Not only are different studies' results incomparable due to variability in cognitive measures’ selected facets, but it has long been demonstrated in the allied domains of organisational and consumer psychology that affectively and cognitively conceived and operationalised satisfaction with jobs and consumption, respectively, are both differently predicted and have different outcomes (Organ and Near 1985; Brief and Roberson 1989; Moorman 1993; Homburg, Koschate, and Bayless 2006; Kaplan et al. 2009; Thompson and Phua 2012). Hence, conceptualising student satisfaction affectively but then measuring it cognitively may result in misleading findings: not only is it unlikely that any particular selected set of specific facets of an educational experience will fully explain variance in affective student satisfaction, it also erroneously conflates cause with effect. While satisfaction with selected cognitive facets of an educational experience may each partially contribute towards affective student satisfaction, as Cheng and Marsh $(2010,697)$ stress, they will not in and of themselves encompass affective student satisfaction.

We explicitly conceptualise overall $\mathrm{PhD}$ student satisfaction as an affective construct. We seek to assess the influence on PhD student satisfaction of the supportiveness and academic qualities of, respectively, supervisors, departments and PhD peers: we do not assume that these in and of themselves either constitute PhD student satisfaction or account for all but a portion of variance in $\mathrm{PhD}$ student satisfaction. Hence, we sought to measure overall $\mathrm{PhD}$ student satisfaction affectively, directly, reliably, and validly. 
Despite their respective merits, we found extant measures of overall affective student satisfaction suboptimal for our purposes because they variously; have constrained internal consistency reliability resulting from too few, often single, items (e.g. Banwet and Datta 2003; Mai 2005; Appleton-Knapp and Krentler 2006; Douglas et al. 2006; Arena, Arnaboldi, and Azzone 2010; Lenton 2015), or they conflate satisfaction with related but nevertheless distinct constructs (e.g. Bean and Bradley 1986; Palacio, Meneses, and Perez 2002; Schlesinger, Cervera, and Perez-Cabanero 2016), or they incorporate manifestly cognitive items (e.g. Thomas and Galambos 2004; Brown and Mazzarol 2009), or they have somewhat ambiguous or difficult wording (e.g. Ali et al. 2016; James and Casidy 2018). Such features of extant student satisfaction measures may have unfortunate consequences. For example, one nationwide government-sponsored survey which did not employ a multi-item satisfaction scale found that $\mathrm{PhD}$ students' assessments of satisfaction 'were almost completely devoid of reliability', and that the lack of correlation with external validity criteria such as research productivity, award receipt, and attrition rates 'calls into question the construct validity of the responses’' (Marsh, Rowe, and Martin 2002, 339).

Hence, to ensure a direct, purely affective, unidimensional, valid, reliable, and both time- and space-efficient measure, we devised a 10-item lexical measure. We asked: Thinking about your overall experience of your PhD as a whole, how much do you agree that the following words accurately describe your overall $\mathrm{PhD}$ experience to date? A 6-point interval measure running from Strongly Disagree to Strongly Agree was then used to indicate the extent of agreement to the subsequent single-word affective items: Good, Unhappy, Enjoyable, Satisfactory, Bad, Terrible, Excellent, Disappointing, Happy, Unsatisfactory. The mixed valance of these items was designed to reduce response set and acquiescence responding (Knowles and Nathan 1997). An exploratory principal component analysis found the scale to 
be unidimensional, with a single component accounting for $67 \%$ of variance, and no factor loading below .73. Cronbach’s alpha of internal consistency reliability is .94.

\section{Independent variables}

We assessed PhD candidates’ actual experience of, respectively, the supportiveness and academic qualities of, discretely, supervisors, departments and peers. As we could locate neither explicit nor consistent implicit definitions, or suitable measures, of either construct in extant research, we devised bespoke and maximally space- and time-efficient measures applicable broadly and plausibly to, respectively, supervisors, departments, and peer-groups.

Procedurally, we sought to derive clear and concise definitions of the constructs of supportiveness and academic qualities from a $\mathrm{PhD}$ candidate perspective through means of a focus group discussion with $13 \mathrm{PhD}$ candidates at one author's university. These were pursuing PhDs across a range of subjects and came from 11 countries (Britain, China, Germany, Greece, India, Ireland, Romania, Saudi Arabia, South Korea, Turkey and the United States). We initiated discussion by framing the notions of supportiveness and academic qualities in the context of extant research on both, and were thereby able to use a deliberately broad, vague, non-leading and tentative idea of each construct as a basis on which to proceed.

The notion of supportiveness was found to be a cognitive perception of receiving not so much practical or systematised support, but an overall sense of having a constructively concerned, thoughtful, understanding and reassuring environment. This was regarded as applying similarly to supervisors, peers, and departments. Employing this conceptualisation, and the words used by focus-group participants themselves, we put together a parsimonious 5item lexical scale with face validity that covered the domain of supportiveness without redundancy. We used the question stem: 'From your personal experience, how much do you 
agree that your (supervisor(s)/department or school/peer-group, as appropriate) is(are);' then the item words Caring, Considerate, Encouraging, Supportive, and Sympathetic.

The notion of academic qualities prove to be regarded straightforwardly as a cognitive perception of being, in the succinct words of one participant, 'scholastically highbrow'. In discussing the construct in relation to both supervisors and peer-groups, participants used words like clever, intelligent, smart, knowledgeable, educated, intellectual, academic, cerebral, learned, and scholarly. In discussing the same construct in relation to departments, participants did use a few similar terms, such as intellectual, but mainly used terms like scholarly standing, research reputation, and academic quality, reflecting a department's non-person and more institutional nature. Accordingly, we deemed constructing a single, parsimonious, and nonredundant scale applicable alike to supervisors and peer-groups and also to departments would be inappropriate: the wording would necessarily be awkward and likely fail directly to tap accurately the common underlying construct of academic quality in relation to both people (supervisors and peer-groups) and an institution (departments). Hence, we constructed a 4-item lexical measure for application commonly to both supervisors and peer-groups, using the same question stem as for supportiveness, and comprising the words Intelligent, Knowledgeable, Intellectual, and Scholarly. For departments we substituted those items with Famous in its field, Hard to get into, Prominent for its research, and Renowned for its quality. The internal consistency reliability of Supportiveness for supervisor(s) was $\alpha .83$, for department $\alpha .87$, and for peers $\alpha .89$; and for Academic Qualities internal consistency reliability for supervisor(s) was $\alpha .83$, for department $\alpha .82$, and for peers $\alpha .91$.

\section{Control variables}

Because ours is an international, cross-disciplinary and convenience sample, we sought to control germane variables to derive more generalisable findings. 
Age and sex. Student satisfaction has been linked to age (Muijs and Bohove 2017) and sex (Umbach and Porter 2002), hence we controlled for these.

National PhD procedural heterogeneity. While the nature of PhD research has many commonalities across countries, national differences in supervisory arrangements, taught training, and other areas exist that might affect PhD satisfaction. Accordingly, we controlled for country of $\mathrm{PhD}$ institution, creating dummy variables for each country from which over 5\% of total responses were derived, resulting in dummies for British, American, Australian, and (non-British) European universities.

University quality. As we are interested in the effect of department characteristics on $\mathrm{PhD}$ satisfaction rather than the university in which this might be set, we sought to control for university quality. We did this primarily in terms of research by using publicly available university rankings as a preliminary guide, albeit doing so fully cognisant of the different and sometimes specious criteria used by such rankings (Times Higher Education 2016; TopUniversities 2016; U.S. News Education 2016). To create clear and maximally discrete categories, we defined one dummy to include institutions that might arguably find consensus as being among leading research universities both nationally and internationally. This included such institutions as Australian National University, Cambridge, Harvard, Imperial College, London School of Economics, Oxford, Stanford, and others, and were represented by 98 students in our sample. At the opposite end of the spectrum we created a category of universities that did not appear in any international ranking, or are generally known to be predominantly teaching oriented. Some 57 respondents were studying at universities in this category. The remaining mid-ranking universities comprised 254 respondents and were used as the reference category variable.

Years and mode of study. From professional experience supervising $\mathrm{PhDs}$ and managing $\mathrm{PhD}$ programs we have noted an apparent decline in $\mathrm{PhD}$ candidate satisfaction 
related to how many years they have been on their program, hence we controlled for years of study. As a corollary, we also control for full or part-time mode of study.

Field of study. As the nature of PhD study varies considerably across disciplines (Pole 1998; Egan et al. 2009), we controlled for field of study, aggregating these into social sciences and sciences, with other disciplines in arts and humanities used as a reference category variable.

\section{Results and discussion}

To check for possible multicollinearity problems stemming from method variance, we ran regression diagnostics. The mean Variance Inflation Factor (VIF) across all variables was 1.96, with no VIF over 4.84, well below the rule-of-thumb suggested by Hair et al. (1995) of 10.00 as indicative of potential multicollinearity problems, and below the more stringently conservative 5.00 suggested by Ringle, Wende, and Becker (2015).

Table 2 shows regressions entering supervisor, department, and peer-group variables separately. Model 1 serves as a baseline entering only control variables. Models 2, 3, 5, 6, 8 and 9 show that, respectively, supervisor, department and peer academic qualities and supportiveness separately each predict $\mathrm{PhD}$ student satisfaction, and each significantly increases explained variance in PhD satisfaction over the baseline Model 1 of controls alone. Thus our propositions P1a through P3b are supported.

$$
\text { = INSERT TABLE } 2 .=
$$

Models 4, 7 and 10 each combine both the academic qualities and supportiveness of, respectively, supervisor, department, and peers. The respective explained variances in $\mathrm{PhD}$ student satisfaction support the hierarchy of relative importance predicted in propositions P4a and P4b, with supervisor being the largest predictor of $\mathrm{PhD}$ student satisfaction followed by department then peers. Models 4, 7 and 10 also reveal that for both supervisor and department, 
supportiveness is a larger predictor of $\mathrm{PhD}$ student satisfaction than academic qualities, but that for peers academic qualities is significant whereas supportiveness is not.

Table 3 shows regressions entering supervisor, department, and peer variables in combination. To examine whether academic qualities overall or supportiveness overall explains more variance in $\mathrm{PhD}$ student satisfaction, Model 1 enters only academic qualities for supervisor, department, and peers combined, while Model 2 enters only supportiveness for supervisor, department, and peers combined. The significantly higher $(p<.01)$ variance in $\mathrm{PhD}$ student satisfaction explained by supportiveness overall tends to support our proposition (P5), that supportiveness overall is more important than academic qualities overall to $\mathrm{PhD}$ student satisfaction.

\section{$=$ INSERT TABLE 3. =}

Finally, Model 3 enters simultaneously for supervisor, department and peers both academic qualities and supportiveness, thereby controlling for any covariance across variables and hence revealing the unique effect of each. In this full model, only supervisor supportiveness and the academic qualities and supportiveness of the department retain significant effects on PhD student satisfaction. Of these, supervisor supportiveness has the largest beta, followed by department supportiveness, then department academic qualities.

In sum, therefore, we find that; (i) supervisors are the largest contributors to $\mathrm{PhD}$ student satisfaction, but this is driven solely through their supportiveness and not academic qualities, (ii) likewise supportiveness overall is more important than academic qualities overall, (iii) that departments really matter in regards both to supportiveness and academic qualities, and (iv) peers overall have no independent effects on $\mathrm{PhD}$ student satisfaction.

These findings do not categorically contradict prior research suggesting the academic qualities of supervisors are important to PhD student satisfaction (e.g. Donald, Saroyan, and 
Denison 1995; Zhao, Golde, and McCormick 2007; Bedggood and Donovan 2012). However, they do suggest that in the context of wider department academic qualities combined with supportiveness from both supervisor and department, the academic qualities of supervisors are less salient. This result would seem consonant with recent trends towards $\mathrm{PhD}$ programmes that both increasingly incorporate supervisory teams rather than single supervisors, and provide more formal research training that is often department- rather than supervisor led.

Our findings also seem to suggest that when $\mathrm{PhD}$ students' supervisory and departmental support needs are met, their satisfaction with their $\mathrm{PhD}$ is not affected by either peer academic qualities or peer supportiveness. While this contrasts somewhat with research at the undergraduate and master levels (e.g. Harnash-Glezer and Meyer 1991; Volkwein and Carbone 1994; Baldwin, Bedell, and Johnson 1997; Wiers-Jenssen, Stensaker, and Grogaard 2002), we suspect our finding here may reflect two things. First, the less taught-class and more ‘individual nature’ (Slight 2017, 43) of PhD study that, relatively speaking, limits structured contact between PhD student peers, and second, the vastly greater salience of supervisors and other experienced scholars in guiding and supporting a successful PhD. Nonetheless, to unpick whether this apparent insignificance of peers is in fact universally applicable to all $\mathrm{PhD}$ study or merely an artefact of particular institutional circumstance, future research could investigate the extent to which extensively 'taught' or cohort PhDs, whose programs more actively incorporate shared training and development activities, also exhibit the same characteristics.

The significance of multiform sources of both expertise and support to $\mathrm{PhD}$ student outcomes has been noted for some time (e.g. Rudd 1975; Welsh 1979; Winfield 1987; Elton and Pope 1989), and continues to attract considerable research attention. Recent studies by, for example, Pearson, Evans, and Macauley (2016) and Spronken-Smith, Cameron, and Quigg (2018) highlight the value of PhD student access to diverse resources and networks, while Baker and Pifer (2015) and Bastalich (2017) stress the importance of PhD candidate 
assimilation into the relevant academic community, and Posselt (2018) underscores the wideranging 'holistic' faculty support necessary for effective $\mathrm{PhD}$ progression. Given the relatively advanced and technical skills required to succeed in research environments, it is perhaps not surprising that the cultivation of such 'communities of practice' (Tight 2015, 115) appears especially germane to the context of $\mathrm{PhD}$ study. Yet with regard to student satisfaction specifically, to the authors' knowledge, this is the first study to have categorised, identified, and quantified aspects of this importance at the PhD level. Future research seeking to yield further insights into the nature of these effects might therefore usefully contrast the relative importance of these same determinants of student satisfaction across other levels and domains of higher education whose inherent characteristics differ.

\section{Conclusions}

Our study makes an original and timely contribution to the understanding of $\mathrm{PhD}$ student satisfaction by adding some clarity and structure to the separate and combined effects of supervisor, department and peers, in terms both of academic qualities and of supportiveness. We find that each of these three facets of the $\mathrm{PhD}$ experience separately are found to be significant, while supervisors have the greatest impact on satisfaction, followed by department, then peers, and supportiveness across these three groups is more influential than academic qualities. Furthermore, when all factors are assessed concurrently, only the influences of supervisor supportiveness along with both department academic qualities and supportiveness appear to predict PhD student satisfaction, and by corollary that supervisor academic qualities and peers overall are insignificant.

Before drawing out potential implications of these findings, the limitations of our research must be kept in mind. The size and composition of our sample are in line with, and in certain respects improve on, some prior research, and are adequate for our general purpose. However, we obtained insufficient data to allow highly nuanced analyses by, for example, 
country of $\mathrm{PhD}$ institution, discipline, or nationality of student. Clearly, given the heterogeneous nature of PhD programmes by discipline and other dimensions such as country, far larger samples, if feasibly collectable, would be advantageous in shedding additional light on the determinants of $\mathrm{PhD}$ student satisfaction. Ours is also a convenience sample, and we were obliged to use several pertinent controls to help attenuate possible biases sometimes attendant with such samples. Notwithstanding our efforts at mitigation here, our findings are subject to the standard criticisms of non-probability sampling bias, namely possible nonrepresentativeness and constrained generalisability. Furthermore, like all analyses based on survey data, ours are potentially susceptible to method variance. While we deliberately ensured the design of our instrument and scales took this into account, by for example using positively and negatively valanced items, method variance may potentially influence the absolute effect sizes of our analyses. However, that said, method variance would not influence the relative magnitude of effect sizes we found, meaning the hierarchy of effects we report is likely robust. We also note the caveat that the different wording it was necessary to use in measuring academic qualities in relation to departments, on one hand, and to supervisors and peers on the other, may in some degree affect their absolute direct scalar equivalence, if not necessarily their relative qualitative meaning or hierarchy.

Limitations notwithstanding, our results suggest that to increase $\mathrm{PhD}$ student satisfaction universities might usefully focus on improving the academic expertise of their departments as a whole while ensuring that supportiveness both at department and, especially, supervisory levels are of a high standard. At the same time, this implies that $\mathrm{PhD}$ supervisors and their departments should perhaps seek to work jointly, and perhaps more closely than many currently do. Additional strategic implications extend to human resource management where attracting single 'star' academics, for instance, would seem to be less advantageous than equivalent efforts at cultivating more broadly collegial but capable faculties. 
Of course, simply asking supervisors or departments to be more cooperatively supportive of $\mathrm{PhD}$ students is unlikely to be effective unless precisely what constitutes supportiveness is known in worthwhile detail. We have deliberately used a broad construct of supportiveness to tap a general sentiment rather than any specific practical actions. No doubt supportiveness does comprise in part being caring and sympathetic, for example, but efforts to build on our results might begin by attempting to find out exactly what $\mathrm{PhD}$ students do and do not regard as meaningfully useful and practically implementable supportiveness. Hence, for our own study now to be translated into actions that universities can use to enhance the competitiveness of their levels of PhD student satisfaction, we would urge that a future research agenda in the area include unpacking direct from a $\mathrm{PhD}$ student perspective the practical constituents of supervisor and departmental supportiveness: they will likely have elements that are the same, but may well have elements that differ. 


\section{References}

Ali, F., Y. Zhou, K. Hussain, P. K. Nair, and N. A. Ragavan. 2016. “Does Higher Education Service Quality Effect Student Satisfaction, Image and Loyalty? A Study of International Students in Malaysian Public Universities.” Quality Assurance in Education 24 (1): 70-94. doi:10.1108/QAE-02-2014-0008.

Allen, J., and D. Davis. 1991. "Searching for Excellence in Marketing Education: The Relationship between Service Quality and Three Outcome Variables.” Journal of Marketing Education 13 (1): 47-55. doi:10.1177/027347539101300106.

Appleton-Knapp, S. L., and K. A. Krentler. 2006. “Measuring Student Expectations and Their Effects on Satisfaction: The Importance of Managing Student Expectations.” Journal of Marketing Education 28 (3): 254-264. doi:10.1177/0273475306293359. Arambewela, R., and J. Hall. 2013. "The Interactional Effects of the Internal and External University Environment, and the Influence of Personal Values, on Satisfaction among International Postgraduate Students.” Studies in Higher Education 38 (7): 972-988. doi:10.1080/03075079.2011.615916.

Arena, M., M. Arnaboldi, and G. Azzone. 2010. "Student Perceptions and Central Administrative Services: The Case of Higher Education in Italy.” Studies in Higher Education 35 (8): 941-959. doi:10.1080/03075070903420708.

Astin, A. W. 1993. What Matters in College: Four Critical Years Revisited. San Francisco: Jossey Bass.

Athiyaman, A. 1997. "Linking Student Satisfaction and Service Quality Perceptions: The Case of University Education.” European Journal of Marketing 31 (7): 528-540. doi:10.1108/03090569710176655. 
Baker, V. L., and M. J. Pifer. 2015. “Antecedents and Outcomes: Theories of Fit and the Study of Doctoral Education.” Studies in Higher Education 40 (2): 296-310. doi:10.1080/03075079.2013.823936.

Baldwin, T. T., M. D. Bedell., and J. L. Johnson. 1997. “The Social Fabric of a Team-based MBA Program: Network Effects on Student Satisfaction and Performance.” Academy of Management Journal 40 (6): 1369-1397. doi:10.5465/257037.

Banwet, D. K., and B. Datta. 2003. “A Study of the Effect of Perceived Lecture Quality on Post-Lecture Intentions.” Work Study 52 (5): 234-243. doi:10.1108/00438020310485967.

Barnes, B. J., and J. Randall. 2012. “Doctoral Student Satisfaction: An Examination of Disciplinary, Enrollment, and Institutional Differences.” Research in Higher Education 53 (1): 47-75. doi:10.1007/s11162-011-9225-4.

Bastalich, W. 2017. “Content and Context in Knowledge Production: A Critical Review of Doctoral Supervision Literature.” Studies in Higher Education 42 (7): 1145-1157. doi:10.1080/03075079.2015.1079702.

Bean, J. P., and R. K. Bradley. 1986. "Untangling the Satisfaction-Performance Relationship for College Students.” The Journal of Higher Education 57 (4): 393-412. doi:10.1080/00221546.1986.11778785.

Bedggood, R. E., and J. D. Donovan. 2012. “University Performance Evaluations: What Are We Really Measuring?” Studies in Higher Education 37 (7): 825-842. doi:10.1080/03075079.2010.549221.

Berbegal-Mirabent, J., M. Mas-Machuca, and F. Marimon. 2016. "Is Research Mediating the Relationship between Teaching Experience and Student Satisfaction?” Studies in Higher Education 43 (6): 1-20. doi:10.1080/03075079.2016.1201808. 
Berger, J. B., and J. M. Braxton. 1998. "Revising Tinto's Interactionalist Theory of Student Departure through Theory Elaboration: Examining the Role of Organizational Attributes in the Persistence Process.” Research in Higher Education 39 (2): 103-119. doi:10.1023/A:1018760513769.

Borden, V. M. H. 1995. “Segmenting Student Markets with a Student Satisfaction and Priorities Survey.” Research in Higher Education 36 (1): 73-88. doi:10.1007/BF02207767.

Boud, D., and A. Lee. 2005. "Peer Learning as Pedagogic Discourse for Research Education.” Studies in Higher Education 30 (5): 501-16. doi:10.1080/03075070500249138.

Brief, A. P., and L. Roberson. 1989. “Job-Attitude Organization-An Exploratory Study.” Journal of Applied Social Psychology 19: 717-727. doi:10.1111/j.15591816.1989.tb01254.x.

Brown, R. M., and T. W. Mazzarol. 2009. “The Importance of Institutional Image to Student Satisfaction and Loyalty within Higher Education.” Higher Education 58 (1): 81-95. doi:10.1007/s10734-008-9183-8.

Cheng, J. H. S., and H. W. Marsh. 2010. "National Student Survey: Are Differences between Universities and Courses Reliable and Meaningful?” Oxford Review of Education 36 (6): 693-712. doi:10.1080/03054985.2010.491179.

Clemes, M. D., C. E. C. Gan, and T. Kao. 2007. "University Student Satisfaction: An Empirical Analysis.” Journal of Marketing for Higher Education 17 (2): 292-325. doi:10.1080/08841240801912831.

de Kleijn, R. A. M., M. T. Mainhard, P. C. Meijer, A. Pilot, and M. Brekelmans. 2012. “Master's Thesis Supervision: Relations between Perceptions of the SupervisorStudent Relationship, Final Grade, Perceived Supervisor Contribution to Learning and 
Student Satisfaction.” Studies in Higher Education 37 (8): 925-939.

doi:10.1080/03075079.2011.556717.

Deanne, G., G. Teegan, and P. Mertova. 2018. "So How Big Is Big? Investigating the Impact of Class Size on Ratings in Student Evaluation.” Assessment \& Evaluation in Higher Education 43 (2): 175-184. doi:10.1080/02602938.2017.1317327.

Deem, R., and K. J. Brehony. 2000. “Doctoral Students’ Access to Research Cultures-Are Some More Unequal than Others?” Studies in Higher Education 25 (2): 149-165. doi:10.1080/713696138.

Donald, J. G., A. Saroyan, and D. B. Denison. 1995. “Graduate Student Supervision Policies and Procedures: A Case Study of Issues and Factors Affecting Graduate Study.” Canadian Journal of Higher Education 25 (3): 71-92.

Donohue, T. L., and E. H. Wong. 1997. “Achievement Motivation and College Satisfaction in Traditional and Nontraditional Students.” Education 118 (2): 237-244.

Douglas, J., A. Douglas, and B. Barnes. 2006. “Measuring Student Satisfaction at a UK University.” Quality Assurance in Education 14 (3): 251-267. doi:10.1108/09684880610678568.

Egan, R., D. Stockley, B. Brouwer, D. Tripp, and N. Stechyson. 2009. "Relationships between Area of Academic Concentration, Supervisory Style, Student Needs and Best Practices.” Studies in Higher Education 34 (3): 337-345. doi:10.1080/03075070802597143.

Elliott, K. M., and M. A. Healy. 2001. “Key Factors Influencing Student Satisfaction Related to Recruitment and Retention.” Journal of Marketing for Higher Education 10 (4): 111. doi:10.1300/J050v10n04_01. 
Elliott, K. M., and D. Shin. 2002. "Student Satisfaction: An Alternative Approach to Assessing this Important Concept.” Journal of Higher Education Policy and Management 24 (2): 197-209. doi:10.1080/1360080022000013518.

Elton, L., and M. Pope. 1989. "Research Supervision: The Value of Collegiality.” Cambridge Journal of Education 19 (3): 267-276. doi:10.1080/0305764890190302.

Erichsen, E. A., D. Bolliger, and C. Halupa. 2014. "Student Satisfaction with Graduate Supervision in Doctoral Programs Primarily Delivered in Distance Education Settings.” Studies in Higher Education 39 (2): 321-338.

doi:10.1080/03075079.2012.709496.

Fenge, L. 2012. “Enhancing the Doctoral Journey: The Role of Group Supervision in Supporting Collaborative Learning and Creativity.” Studies in Higher Education 37 (4): 401-414. doi:10.1080/03075079.2010.520697.

Gardner, S. K. 2007. “”I Heard It through the Grapevine”: Doctoral Student Socialization in Chemistry and History.” Higher Education 54: 723-740. doi:10.1007/s10734-0069020-x.

Gibbons, S., E. Neumayer, and R. Perkins. 2015. “Student Satisfaction, League Tables and University Applications: Evidence from Britain.” Economics of Education Review 48: 148-164. doi:10.1016/j.econedurev.2015.07.002.

Gibson, A. 2010. “Measuring Business Student Satisfaction: A Review and Summary of the Major Predictors.” Journal of Higher Education Policy and Management 32 (3): 251259. doi:10.1080/13600801003743349.

Girves, J. E., and V. Wemmerus. 1988. “Developing Models of Graduate Student Degree Progress.” The Journal of Higher Education 59 (2): 163-189. doi:10.1080/00221546.1988.11778320. 
Golde, C. M. 2005. “The Role of the Department and Discipline in Doctoral Student Attrition: Lessons from Four Departments.” The Journal of Higher Education 76 (6): 669-700. doi:10.1080/00221546.2005.11772304.

Gruber, T., S. Fus, R. Voss, and M. Glaser-Zikuda. 2010. “Examining Student Satisfaction with Higher Education Services.” International Journal of Public Sector Management 23 (2): 105-123. doi:10.1108/09513551011022474.

Hair, J. F., R. E. Anderson, R. L. Tatham, and W. C. Black. 1995. Multivariate Data Analysis (3rd ed.). New York: Macmillan.

Han, H., K. Kiatkawsin, W. Kim, and J. Hong. 2018. "Physical Classroom Environment and Student Satisfaction with Courses.” Assessment \& Evaluation in Higher Education 43 (1): 110-125. doi:10.1080/02602938.2017.1299855.

Harnash-Glezer, M., and J. Meyer. 1991. “Dimensions of Satisfaction with Collegiate Education.” Assessment \& Evaluation in Higher Education 16 (2): 95-107. doi:10.1080/0260293910160201.

Helgesen, O., and E. Nesset. 2007. “Images, Satisfaction and Antecedents: Drivers of Student Loyalty? A Case Study of a Norwegian University College.” Corporate Reputation Review 10 (1): 38-59. doi:10.1057/palgrave.crr.1550037.

Hendry, A. M. 1983. "Measuring Adult Student Satisfaction: A Model.” Canadian Vocational Journal 19 (1): 47-50.

Hockey, J. 1994. “New Territory: Problems of Adjusting to the First Year of a Social Science PhD.” Studies in Higher Education 19 (2): 177-190. doi:10.1080/03075079412331382027.

Homburg, C., N. Koschate, and J. L. Bayless. 2006. "The Role of Cognition and Affect in the Formation of Customer Satisfaction: A Dynamic Perspective.” Journal of Marketing 70 (3): 21-31. doi:10.1509/jmkg.70.3.21. 
Husbands, C. T. 1996. "Variations in Students' Evaluations of Teachers' Lecturing and SmallGroup Teaching: A Study at the London School of Economics and Political Science.” Studies in Higher Education 21 (2): 187-206. doi:10.1080/03075079612331381358.

Ives, G., and G. Rowley. 2005. "Supervisor Selection or Allocation and Continuity of Supervision: Ph.D. students’ progress and outcomes.” Studies in Higher Education 30 (5): 535-555. doi:10.1080/03075070500249161.

Jacks, P., D. E. Chubin, A. L. Porter, and T. Connolly. 1983. “The ABCs of ABDs: A Study of Incomplete Doctorates.” Improving College and University Teaching 31 (2): 74-81. doi:10.1080/00193089.1983.10533805.

James, L. T., and R. Casidy. 2018. “Authentic Assessment in Business Education: Its Effects on Student Satisfaction and Promoting Behavior.” Studies in Higher Education 43: 401-415. doi:10.1080/03075079.2016.1165659.

Kam, B. H. 1997. "Style and Quality in Research Supervision: The Supervisor Dependency Factor.” Higher Education 34 (1): 81-103. doi:10.1023/A:1002946922952.

Kaplan, S. A., C. R. Warren, A. P. Barsky, and C. J. Thoresen. 2009. “A Note on the Relationship between Affect(ivity) and Differing Conceptualizations of Job Satisfaction: Some Unexpected Meta-Analytic Findings.” European Journal of Work and Organizational Psychology 18 (1): 29-54. doi:10.1080/13594320701873264.

Knowles, E. S., and K. T. Nathan. 1997. “Acquiescent Responding in Self-reports: Cognitive Style or Social Concern?” Journal of Research in Personality 31 (2): 293-301. doi:10.1006/jrpe.1997.2180.

Krehbiel, T. C., R. H. McClure, and E. Pratsini. 1997. “Using Student Disconfirmation as a Measure of Classroom Effectiveness.” Journal of Education for Business 72 (4): 224229. doi:10.1080/08832323.1997.10116860. 
Kuh, G. D. 2003. “What We're Learning about Student Engagement from NSSE:

Benchmarks for Effective Educational Practices.” Change: The Magazine of Higher Learning 35 (2): 24-32. doi:10.1080/00091380309604090.

Kuh, G. D., J. L. Kinzie, J. A. Buckley, B. K. Bridges, and J. C. Hayek. 2006. What Matters to Student Success: A Review of the Literature. Washington, DC: National Postsecondary Education Cooperative.

LeBlanc, G., and N. Nguyen. 1997. "Searching for Excellence in Business Education: An Exploratory Study of Customer Impressions of Service Quality.” International Journal of Educational Management 11 (2): 72-79. doi:10.1108/09513549710163961.

Lee, A. 2008. “How Are Doctoral Students Supervised? Concepts of Doctoral Research Supervision.” Studies in Higher Education 33 (3): 267-281. doi:10.1080/03075070802049202.

Lenton, P. 2015. “Determining Student Satisfaction: An Economic Analysis of the National Student Survey.” Economics of Education Review 47: 118-127. doi:10.1016/j.econedurev.2015.05.001.

Liegler, R. M. 1997. "Predicting Student Satisfaction in Baccalaureate Nursing Programs: Testing a Causal Model.” Journal of Nursing Education 36 (8): 357-364. doi:10.3928/0148-4834-19971001-04.

Mai, L. 2005. “A Comparative Study between UK and US: The Student Satisfaction in Higher Education and Its Influential Factors.” Journal of Marketing Management 21 (7-8): 859-878. doi:10.1362/026725705774538471.

Martinsuo, M., and V. Turkulainen. 2011. “Personal Commitment, Support and Progress in Doctoral Studies.” Studies in Higher Education 36 (1): 103-120. doi:10.1080/03075070903469598. 
Marsh, H. W., K. J. Rowe, and A. Martin. 2002. “PhD Students’ Evaluations of Research Supervision: Issues, Complexities, and Challenges in a Nationwide Australian Experiment in Benchmarking Universities.” The Journal of Higher Education 73 (2): 313-348. doi:10.1080/00221546.2002.11777151.

Maxwell-Stuart, R., B. Taheri, A. S. Paterson, K. O’Gorman, and W. Jackson. 2018. "Working Together to Increase Student Satisfaction: Exploring the Effects of Mode of Study and Fee Status.” Studies in Higher Education 43 (8): 1-13. doi:10.1080/03075079.2016.1257601.

Moorman, R. H. 1993. “The Influence of Cognitive and Affective Based Job Satisfaction Measures on the Relationship between Satisfaction and Organizational Citizenship Behavior.” Human Relations 46 (6): 759-776. doi:10.1177/001872679304600604.

Morton, M., and G. Thornley. 2001. "Experiences of Doctoral Students in Mathematics in New Zealand.” Assessment \& Evaluation in Higher Education 26 (2): 113-126. doi:10.1080/02602930020018953.

Muijs, D., and C. Bokhove. 2017. "Postgraduate Student Satisfaction: A Multilevel Analysis of PTES Data.” British Educational Research Journal 43 (5): 904-930. doi:10.1002/berj.3294.

Neumann, R., and J. Rodwell. 2009. “The ‘Invisible’ Part-Time Research Students: A Case Study of Satisfaction and Completion.” Studies in Higher Education 34 (1): 55-68. doi:10.1080/03075070802601960.

Organ, D. W., and J. P. Near. 1985. "Cognition vs. Affect in Measures of Job Satisfaction.” International Journal of Psychology 20: 241-253. doi:10.1080/00207598508247735.

Overall, N., K. L. Deane, and E. R. Peterson. 2011. "Promoting Doctoral Students' Research Self-Efficacy: Combining Academic Guidance with Autonomy Support.” Higher 
Education Research and Development 30 (6): 791-805.

doi:10.1080/07294360.2010.535508.

Palacio, A. B., G. D. Meneses, and P. J. P. Perez. 2002. “The Configuration of the University Image and Its Relationship with the Satisfaction of Students.” Journal of Educational Administration 40 (5): 486-505. doi:10.1108/09578230210440311.

Pascarella, E. T., and P. T. Terenzini. 1977. "Patterns of Student-Faculty Informal Interaction beyond the Classroom and Voluntary Freshman Attrition.” The Journal of Higher Education 48 (5): 540-552. doi:10.1080/00221546.1977.11776573.

Pascarella, E. T., and P. T. Terenzini. 1991. How College Affects Students: Findings and Insights from Twenty Years of Research. San Francisco: Jossey-Bass.

Pascarella, E. T., and P. T. Terenzini. 2005. How College Affects Students: A Third Decade of Research. San Francisco: Jossey-Bass.

Pearson, M., T. Evans, and P. Macauley. 2016. “The Diversity and Complexity of Settings and Arrangements Forming the ‘Experienced Environments’ for Doctoral Candidates: Some Implications for Doctoral Education.” Studies in Higher Education 41 (12): 2110-2124. doi:10.1080/03075079.2015.1019449.

Pedro, E., and M. Franco. 2016. “The Importance of Networks in the Transnational Mobility of Higher Education Students: Attraction and Satisfaction of Foreign Mobility Students at a Public University.” Studies in Higher Education 41 (9): 1627-1655. doi:10.1080/03075079.2014.999321.

Pike, G. R. 1993. “The Relationship between Perceived Learning and Satisfaction with College: An Alternative View.” Research in Higher Education 34 (1): 23-40. doi:10.1007/BF00991861. 
Pilbeam, C., and D. Denyer. 2009. “Lone Scholar or Community Member? The Role of Student Networks in Doctoral Education in a UK Management School.” Studies in Higher Education 34 (3): 301-318. doi:10.1080/03075070802597077.

Pilbeam, C., G. Lloyd-Jones, and D. Denyer. 2013. “Leveraging Value in Doctoral Student Networks through Social Capital.” Studies in Higher Education 38 (10): 1472-1489. doi:10.1080/03075079.2011.636800.

Platow, M. J. 2012. “PhD Experience and Subsequent Outcomes: A Look at Self-Perceptions of Acquired Graduate Attributes and Supervisor Support.” Studies in Higher Education 37 (1): 103-118. doi:10.1080/03075079.2010.501104.

Pole, C. 1998. “Joint Supervision and the PhD: Safety Net or Panacea?” Assessment \& Evaluation in Higher Education 23 (3): 259-271. doi:10.1080/0260293980230303. Posselt, J. 2018. “Normalizing Struggle: Dimensions of Faculty Support for Doctoral Students and Implications for Persistence and Well-Being.” The Journal of Higher Education 89 (6): 988-1013. doi:10.1080/00221546.2018.1449080.

Remedios, R., and D. A. Lieberman. 2008. “I Liked Your Course Because You Taught Me Well: The Influence of Grades, Workload, Expectations and Goals on Students’ Evaluations of Teaching.” British Educational Research Journal 34 (1): 91-115. doi:10.1080/01411920701492043.

Ringle, C. M., S. Wende, and J. J. M. Becker. 2015. SmartPLS 3. Bönningstedt: SmartPLS. Roberts, J., and R. Styron Jr. 2010. “Student Satisfaction and Persistence: Factors Vital to Student Retention.” Research in Higher Education Journal; Jacksonville 6: 1-18. Rudd, E. 1975. The Highest Education. London: Routledge \& Kegan Paul. Salmon, P. 1992. Achieving a PhD: Ten Students' Experience. Sterling, VA: Stylus Publishing Inc. 
Schlesinger, W., A. Cervera, and C. Perez-Cabanero. 2016. "Sticking with Your University: The Importance of Satisfaction, Trust, Image and Shared Values.” Studies in Higher Education 42: 2178-2194. doi:10.1080/03075079.2015.1136613.

Shacham, M., and Y. Od-Cohen. 2009. "Rethinking PhD Learning Incorporating Communities of Practice.” Innovations in Education and Teaching International 46 (3): 279-292. doi:10.1080/14703290903069019.

Slight, C. 2017. Postgraduate Research Experience Survey 2017. Available online at: https://www.heacademy.ac.uk/system/files/hub/download/pres_2017_report_0.pdf (accessed March 7 2018).

Spady, W. G. 1970. "Dropouts from Higher Education: An Interdisciplinary Review and Synthesis.” Interchange 1 (1): 64-85. doi:10.1007/BF02214313.

Spronken-Smith, R., C. Cameron, and R. Quigg. 2018. “Factors Contributing to High PhD Completion Rates: A Case Study in a Research-Intensive University in New Zealand.” Assessment \& Evaluation in Higher Education 43 (1): 94-109. doi:10.1080/02602938.2017.1298717.

Sung, M., and S. Yang. 2009. "Student-University Relationships and Reputation: A Study of the Links between Key Factors Fostering Students’ Supportive Behavioral Intentions towards Their University.” Higher Education 57 (6): 787-811. doi:10.1007/s10734008-9176-7.

Thomas, E. H., and N. Galambos. 2004. "What Satisfies Students? Mining Student-Opinion Data with Regression and Decision Tree Analysis.” Research in Higher Education 45 (3): 251-269. doi:10.1023/B:RIHE.0000019589.79439.6e.

Thompson, E. R., and F. T. T. Phua. 2012. “A Brief Index of Affective Job Satisfaction.” Group and Organization Management 37 (3): 275-307. doi:10.1177/1059601111434201. 
Tight, M. 2015. “Theory Application in Higher Education Research: The Case of Communities of Practice.” European Journal of Higher Education 5 (2): 111-126. doi:10.1080/21568235.2014.997266.

Times Higher Education 2016. World University Rankings 2015-2016. Available online at: https://www.timeshighereducation.com/world-university-rankings/2016/worldranking\#!/page/0/length/25/sort_by/rank/sort_order/asc/cols/stats (accessed March 28 2016).

TopUniversities 2016. QS World University Rankings 2015-2016. Available online at: https://www.topuniversities.com/university-rankings/world-university-rankings/2015 (accessed March 28 2016).

Umbach, P. D., and S. R. Porter. 2002. "How Do Academic Departments Impact Student Satisfaction? Understanding the Contextual Effects of Departments.” Research in Higher Education 43 (2): 209-234. doi:10.1023/A:1014471708162.

U.S. News Education 2016. Best Global Universities Rankings. Available online at: https://www.usnews.com/education/best-global-universities/rankings (accessed March 28 2016)

Volkwein, J. F., and D. A. Carbone. 1994. "The Impact of Departmental Research and Teaching Climates on Undergraduate Growth and Satisfaction.” The Journal of Higher Education 65 (2): 147-167. doi:10.1080/00221546.1994.11778487.

Walsh, E. 2010. “A Model of Research Group Microclimate: Environmental and Cultural Factors Affecting the Experiences of Overseas Research Students in the UK.” Studies in Higher Education 35 (5): 545-560. doi:10.1080/03075070903243092.

Welsh, J. M. 1979. The First Year of Postgraduate Research Study. Guildford: SRHE. 
Wiers-Jenssen, J., B. Stensaker, and J. B. Grogaard. 2002. "Student Satisfaction: Towards an Empirical Deconstruction of the Concept.” Quality in Higher Education 8 (2): 183195. doi:10.1080/1353832022000004377.

Winfield, G. 1987. The Social Science PhD, The ESRC Enquiry on Submission Rates. London: ESRC.

Zhao, C., C. M. Golde, and A. C. McCormick. 2007. "More Than a Signature: How Advisor Choice and Advisor Behaviour Affect Doctoral Student Satisfaction.” Journal of Further and Higher Education 31 (3): 263-281. doi:10.1080/03098770701424983. 
Table 1. Descriptive statistics: means, standard deviations and correlations with PhD students' satisfaction

\begin{tabular}{|c|c|c|c|}
\hline & Mean/(\%) & SD & $\begin{array}{c}\text { Correlations with } \mathrm{PhD} \\
\text { satisfaction }\end{array}$ \\
\hline PhD Satisfaction & 4.55 & 1.04 & - \\
\hline \multicolumn{4}{|l|}{ Controls } \\
\hline Age & 31.84 & 8.24 & -.04 \\
\hline Sex & $(37)$ & - & .03 \\
\hline British & (36) & - & .02 \\
\hline American & $(09)$ & - & -.09 \\
\hline Australian & $(06)$ & - & $.11 *$ \\
\hline European & $(22)$ & - & .04 \\
\hline Leading research university & $(24)$ & - & $-.17 * *$ \\
\hline Teaching oriented university & $(14)$ & - & -.05 \\
\hline Year of study & 2.53 & 1.41 & $-.29 * *$ \\
\hline Full-time & $(88)$ & - & .00 \\
\hline Social sciences & $(52)$ & - & -.06 \\
\hline Sciences & (33) & - & .05 \\
\hline \multicolumn{4}{|l|}{ Experience of factors: } \\
\hline Supervisor: academic qualities & 5.35 & 0.61 & $.45 * *$ \\
\hline Supervisor: supportiveness & 5.25 & 0.64 & $.58 * *$ \\
\hline Department: academic qualities & 4.38 & 0.92 & $.30 * *$ \\
\hline Department: supportiveness & 4.75 & 0.80 & $.50 * *$ \\
\hline Peer: academic qualities & 4.83 & 0.87 & $.31 * *$ \\
\hline Peer: supportiveness & 4.88 & 0.89 & $.28 * *$ \\
\hline
\end{tabular}

Notes. ${ }^{*} \mathrm{p}<.05,{ }^{* *} \mathrm{p}<.01$. Sex dummy coded male 1 . 
Table 2. Regressions showing separate and joint effects of academic qualities and supportiveness of, respectively, supervisors, departments and peers on PhD students' satisfaction.

\begin{tabular}{|c|c|c|c|c|c|c|c|c|c|c|}
\hline & Model 1 & Model 2 & Model 3 & Model 4 & $\underline{\text { Model } 5}$ & Model 6 & Model 7 & Model 8 & Model 9 & $\underline{\text { Model } 10}$ \\
\hline & $\mathrm{SE} \quad \beta$ & $\mathrm{SE} \quad \beta$ & $\mathrm{SE} \quad \beta$ & $\mathrm{SE} \quad \beta$ & $\mathrm{SE} \quad \beta$ & $\mathrm{SE} \quad \beta$ & $\mathrm{SE} \quad \beta$ & $\mathrm{SE} \quad \beta$ & $\mathrm{SE} \quad \beta$ & $\mathrm{SE} \quad \beta$ \\
\hline \multicolumn{11}{|l|}{ Controls } \\
\hline Age & $.01-.04$ & $.01-.05$ & $.01-.01$ & $.01-.02$ & $.01-.06$ & $.01-.04$ & $.01-.05$ & $.01-.05$ & $.01-.04$ & $.01-.05$ \\
\hline Gender & $.10 \quad .04$ & $.09 \quad .03$ & $\begin{array}{ll}.08 & .03 \\
\end{array}$ & $.08 \quad .03$ & $.09 \quad .05$ & $.09 \quad .04$ & $.09 \quad .04$ & $\begin{array}{ll}.10 \quad .07 \\
\end{array}$ & $.10 \quad .07$ & $.10 \quad .07$ \\
\hline British & $\begin{array}{ll}.13 \quad .02 \\
\end{array}$ & $.12 \quad .02$ & $.11 \quad .05$ & $.11 \quad .05$ & $.12 \quad .04$ & $.12 \quad .07$ & $\begin{array}{ll}.11 \quad .07 \\
\end{array}$ & $.13-.02$ & $.13-.02$ & $.13-.03$ \\
\hline American & $.20-.02$ & $.18-.02$ & $.16-.02$ & $.16-.02$ & $.18 \quad .03$ & $.17 \quad .00$ & $.17 \quad .02$ & $.19-.02$ & $.19-.03$ & $.19-.02$ \\
\hline Australian & $.25 .12 *$ & $.22 .12 *$ & $.20 \quad .13 * *$ & $.20 .13 * *$ & $.23 .21 * *$ & $.22 .16 * *$ & $.22 .20 * *$ & $.24 \quad .09$ & $.24 \quad .09$ & $.24 \quad .09$ \\
\hline European & .15 .10 & .13 .10 & $.12 .10 *$ & $.12 .10 *$ & $.14 .12 *$ & $.13 .11 *$ & $.13 .13 *$ & $.14 \quad .09$ & $.14 \quad .09$ & $.14 \quad .09$ \\
\hline $\begin{array}{l}\text { Leading research } \\
\text { university }\end{array}$ & $.13-.14 * *$ & $.12-.11 *$ & $.11-.07$ & $.11-.07$ & $.13-.26 * *$ & $.12-.09$ & $.12-.17 * *$ & $.13-.19 * *$ & $.13-.16 * *$ & $.13-.19 * *$ \\
\hline $\begin{array}{l}\text { Teaching oriented } \\
\text { university }\end{array}$ & $.15-.03$ & .14 .00 & .13 .00 & .13 .00 & $.15 \quad .06$ & $.14-.01$ & $.14 \quad .04$ & $.15-.02$ & $.15-.03$ & $.15-.02$ \\
\hline Years of study & $.04-.26 * *$ & $.03-.22 * *$ & $.03-.18 * *$ & $.03-.18 * *$ & $.03-.23 * *$ & $.03-.18 * *$ & $.03-.18 * *$ & $.03-.23 * *$ & $.04-.24 * *$ & $.03-.23 * *$ \\
\hline Full-time & $.17-.03$ & $.15-.01$ & $\begin{array}{ll}.14 & .01 \\
\end{array}$ & $\begin{array}{ll}.01 & .01 \\
\end{array}$ & $.15-.01$ & $\begin{array}{ll}.15 \quad .00 \\
\end{array}$ & $.14 \quad .00$ & $.16-.02$ & $.16-.01$ & $.16-.02$ \\
\hline Social sciences & $.14-.04$ & $.13-.07$ & $.12-.05$ & $.12-.06$ & $.13-.06$ & $.13-.01$ & $.12-.03$ & $.14-.03$ & $.14-.03$ & $.14-.03$ \\
\hline Sciences & $.16-.03$ & $.15-.05$ & $.13 \quad .05$ & $.13 \quad .03$ & $.15-.07$ & $.14-.05$ & $.14-.08$ & $.16-.04$ & $.16-.03$ & $.16-.04$ \\
\hline
\end{tabular}

\section{Main effects}

Supervisor:

academic qualities

supportiveness

$.05 .42 * *$

- $\quad .04 .56^{* *} \quad .05 .47^{* *} \quad-$

Department:

academic qualities

$\begin{array}{lllll}.04 & .56 * * & .05 & .47 * * & -\end{array}$

supportiveness

$-\quad-$

$.05 .41 * *$

$.05 .24 * * \quad-$

Peer:

academic qualities

supportiveness

\begin{tabular}{rcccccccccc}
\hline$R^{2}$ & .124 & .297 & .398 & .432 & .261 & .301 & .341 & .217 & .168 & .217 \\
\hline F Statistic & $4.67^{* *}$ & $12.85^{* *}$ & $21.79^{* *}$ & $21.41^{* *}$ & $10.72^{* *}$ & $14.54^{* *}$ & $16.04^{* *}$ & $8.40^{* *}$ & $7.36^{* *}$ & $7.78^{* *}$ \\
\hline$\Delta R^{2}$ & & $.173^{* *}$ & $.294^{* *}$ & $.308^{* *}$ & $.137^{* *}$ & $.201^{* *}$ & $.239^{* *}$ & $.093^{* *}$ & $.071^{* *}$ & $.093^{* *}$ \\
\hline
\end{tabular}

Notes. $* \mathrm{p}<.05, * * \mathrm{p}<.01$. Betas standardised. 
Table 3. Regressions showing effects on PhD students' satisfaction of academic qualities, supportiveness, and both combined across supervisor, department and peers

\begin{tabular}{|c|c|c|c|c|c|c|}
\hline & \multicolumn{2}{|c|}{ Model 1} & \multicolumn{2}{|c|}{ Model 2} & \multicolumn{2}{|c|}{ Model 3} \\
\hline & $\mathrm{SE}$ & $\beta$ & $\mathrm{SE}$ & $\beta$ & SE & $\beta$ \\
\hline \multicolumn{7}{|c|}{ Controls } \\
\hline Age & .01 & -.06 & .01 & -.02 & .01 & -.03 \\
\hline Sex & .09 & .05 & .08 & .04 & .08 & .04 \\
\hline British & .11 & .01 & .11 & .05 & .10 & .06 \\
\hline American & .17 & .01 & .15 & -.02 & .15 & .01 \\
\hline Australian & .22 & $.16 * *$ & .20 & $.13 *$ & .20 & $.17 * *$ \\
\hline European & .13 & $.11 *$ & .11 & $.11 *$ & .11 & $.12 * *$ \\
\hline Leading research university & .12 & $-.20 * *$ & .10 & -.07 & .11 & $-.13 * *$ \\
\hline Teaching oriented university & .14 & .05 & .12 & .00 & .12 & .04 \\
\hline Years of study & .03 & $-.21 * *$ & .03 & $-.15 * *$ & .03 & $-.15 * *$ \\
\hline Full-time & .14 & -.01 & .13 & .02 & .13 & .02 \\
\hline Social sciences & .12 & -.07 & .11 & -.03 & .11 & -.05 \\
\hline Sciences & .14 & -.07 & .13 & .02 & .13 & -.01 \\
\hline
\end{tabular}

Main effects

\section{Supervisor:}

academic qualities

.06

supportiveness

$-$

.30

$* *$

.

$43 * *$

.06

.07

Department:

academic qualities

.05

$.24 * *$

supportiveness

$-$

.04

.05

$\begin{array}{ll}.05 & .16^{* *} \\ .04 & .17^{* *}\end{array}$

Peer:

academic qualities

\begin{tabular}{rr} 
& .05 \\
& - \\
\hline$R^{2}$ & .361 \\
\hline F Statistic & $14.79^{* *}$ \\
$\Delta R^{2}$ & $.237^{* *}$
\end{tabular}
.05

$.12 *$

supportiveness

Notes. ${ }^{*} \mathrm{p}<.05,{ }^{* *} \mathrm{p}<.01$. Betas standardised. $\Delta R^{2}$ is from Model 1 Table 2 .

\begin{tabular}{|c|c|c|c|}
\hline$R^{2}$ & .361 & .471 & .499 \\
\hline F Statistic & $14.79 * *$ & $23.34 * *$ & $21.62 * *$ \\
\hline$\Delta R^{2}$ & $.237 * *$ & $.347 * *$ & $.375^{* *}$ \\
\hline
\end{tabular}

